\title{
Strategy Development and Promotion of Tourism in Romania
}

\author{
Gabriela Elena CSOKA, Gabriella KECSE
}

\begin{abstract}
Europe is the world's favorite tourist destination. Tourism plays an essential role in the development of many European regions, especially the less developed regions, due to its considerable potential for contagion and job creation, especially among young people. Tourism has also shown significant resilience, steadily rising during the recent crisis. The European Regional Development Fund (ERDF) supports the competitiveness, sustainability and quality of tourism at regional and local level. Tourism is undoubtedly closely linked to the use and development of natural, historical and cultural capital, and to the attractiveness of cities and regions as living, working and leisure activities. At the same time, it is closely related to the development, innovation and diversification of visitors' products and services. The launch of a cultural tourism business requires funding, which can be from its own resources or can be obtained from another. When a company generates financing from its own sources, ie from its own assets, from its own profits, we call it an internal source of funding.
\end{abstract}

Index Terms- Tourism, society, culture, funding, traditions.

\section{INTRODUCTION}

The importance of knowing the identity values capital at individual, community and national level, for understanding and dedication of their place in the world because is essential, because "Nothing seems to be more important to an individual or an ethnic group, but to become aware of itself as more precisely, and on this basis to ensure a more harmonious integration in the world "(Alexandru Zub, historian, correspondent member of the Romanian Academy) [1].

Supporting the preservation of local heritage and traditions is also extremely important in terms of economic development of rural areasă[3]. Agro-tourism services, crafts and traditional activities can be a way to promote and increase the attractiveness of Romanian villages, with a positive effect on attracting tourists and economic benefits for the local population. Investments in local heritage have a positive impact on the preservation and promotion of local specificities and the development of rural tourism. Thus, in the period 2007-2013, projects aimed at promoting local heritage, rural heritage and traditional products and the development of craft, handicraft and other traditional non-agricultural activities with local specificities were funded through measures: 313 - "Encouraging activities tourism", 312 - "Support for the creation and development of micro-enterprises" and 322 - "Renovation, development of villages and improvement of the rural heritage"[9].

Gabriela Elena CSOKA, PhD, Faculty of Economics, University of Oradea, Oradea, Romania

Gabriella KECSE, PhD, Faculty of Economics, University of Oradea, Oradea, Romania
In the next programming period, the development of rural infrastructure, basic services and the protection of local cultural heritage will be realized through the measure of investment in basic services and the renewal of villages, respectively sub-measures 7.2 and 7.6. The $\boldsymbol{L E A D E R}$ measure will add value by implementing local strategies in the context of local needs and innovative projects. This approach will also facilitate access to ICT infrastructure and encourage rural communities to harness and promote resources and traditions, offering equal opportunities for young people, women, elderly people, people with disabilities and members of national minorities. The LEADER measure approached for investment types that are not funded by the classic NRDP (National Rural Development Program) measures 2014-2020 will cover the gap between rural and urban areas, preserving local identity and stimulating the coagulation of community institutions.

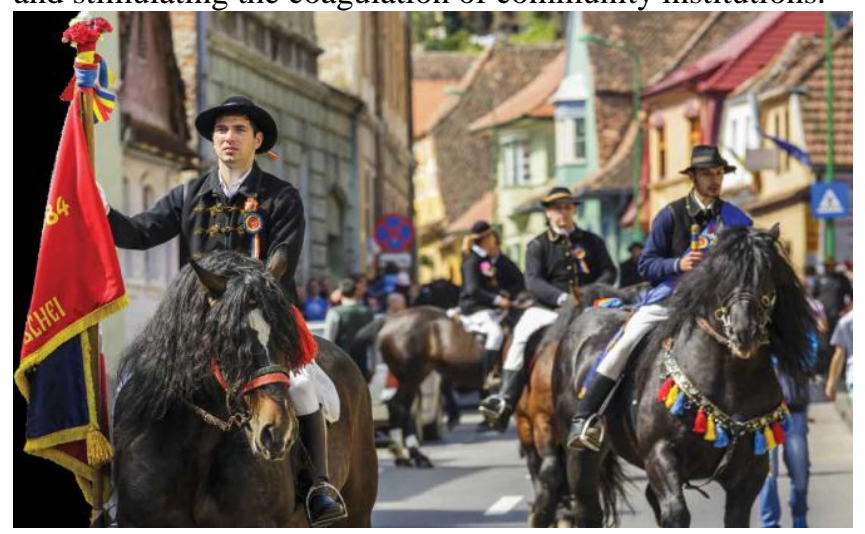

Successful implementation of the measure NRDP 2014-2020 will not only depend on ensuring financial support but also on the existence of good ideas for new projects that promote cultural heritage and contribute to the development of rural businesses and rural communities. [10].

Tourism has long been viewed as an agent of economic development that has not been able to offer the services expected from its customers at all times and has produced unintended impacts. The more tourism studies are made, the more complex it is to be found, and what social, cultural, political, environmental and economic implications can be present. Some foreigners say that Romania is the hidden and still undiscovered treasure of Europe. They also say it could be the only place on the mainland where you can taste the special atmosphere of the past centuries. In the cities of Romania, you can live history, meet special people and discover a world that combines tradition with the modern aspect of life. Tourism represents for Romania the economic sector that has a valuable development potential, which is still untapped and can become a source of attraction for both foreign investors and tourists, but this is hampered by the strong competition from the neighboring countries (Hungary, 
Bulgaria, Croatia) and the extent of the problems related to the competitiveness of Romanian tourism[2].

\section{CONSERVATION OF THE ROMANIAN CULTURAL HERITAGE}

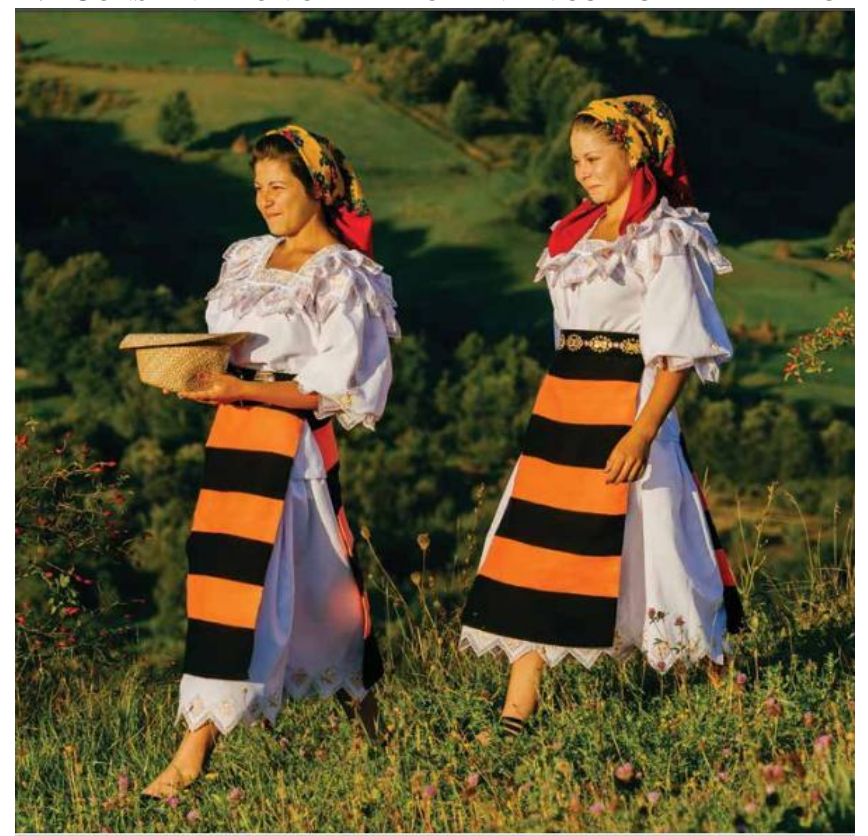

Festivals play an important role in transforming a multicultural society into an intercultural society, which is a strategic step in the integration process [1]. With a history of less than two years in Romania, the phenomenon of street culinary festivals is experiencing a real explosion. Starting in 2017, there were 30 to 40 street food events, which popularized new business concepts in HORECA, followed by Bucharest, Cluj-Napoca, Oradea, the Litoral and in the big cities in the country[2].

First, festivals attract a very wide audience. The number of people attending festivals keeps increasing, which shows a growing interest in the events organized by them. It is very important to communicate the principles of intercultural dialogue to a very large number of people because we cannot speak of intercultural interaction as long as people have no means of getting in touch with each other [7].

The festivals offer artists from the world of the world the opportunity to develop their artistic experience, thus initiating a process of exchange of experience in the field of artistic excellence between different countries. For example, artistic residency programs allow artists to live and work in a new context and to complement their own experiences with local tradition, thus creating a good example of integration. Unlike what is happening in the media, the public who participates in the events organized in the festivals is encouraged to take an active part in these events. Festivals, thought to be some moments of communion open a large number of people reinforce the idea of participation and promote a sense of belonging because they are created by a local community but addresses issues of European and international interest. Festivals also boost cultural tourism. Millions of visitors choose each year to participate in different festivals organized in different countries and localities, thus coming into contact with other cultures and learning new things about other traditions and the history of other places [7].

\section{THE CURRENT SITUATION OF ROMANIAN TOURIST DESTINATIONS}

According to the Development Strategy of the National Development Plan 2007-2013, Romania's great advantage for the development of tourism is offered by the presence of natural and cultural resources of great diversity and harmoniously distributed in the territory, which give the possibility to practice the whole range of forms of tourism[8].

In order to complete the general, poorly diversified tourism offer, Romania has numerous tourist resources to be exploited and capitalized in order to cover the entire calendar year. It is worth mentioning the 18 natural national parks, the protected areas, the Danube Delta biosphere reserve, the richness and diversity of the cultural heritage (monasteries, citadels, churches, monuments), human communities that preserve the values of rural cultural civilization in everyday life, opportunities to practice adventure tourism offered by national rivers, cruise tourism on the Danube River[4].

All this gives Romania the potential for the development of complex tourist products and the increase of the total number of tourists. Also, the opportunities for attracting foreign tourists are more and more diverse: the offer of spa resorts, various forms of business tourism generated by congresses, symposia and exhibitions, diplomatic actions. A problem of national and local importance faced by Romania is represented by the different degree of valorization of tourism potential given the role to be played by respecting the support capacity but also by eliminating the regional economic disparities[3].

In this context, while areas such as Prahova Valley, Braşov, Constanţa and the Black Sea coast have mass tourism at the upper limit and over support capacity in the peak season, in the rest of the tourist areas, the circulation of tourists is half the support and even smaller. The success of urban tourism depends to a large extent on the collaboration between researchers, local authorities, tourism stakeholders and residents. In the field of tourism, the social, economic and environmental effects on the local community are intertwined, overlapped and mutually reinforcing. Because of this, building partnerships is essential when addressing local tourism issues [1].

The Structural and Cohesion Funds (FSC), as financial instruments through which the European Union acts to eliminate economic and social disparities between regions in order to achieve economic and social cohesion, can support the development of tourism as an economic activity, both directly and indirectly. Against the backdrop of the decline in the activity of most economic agents operating in the field of tourism in Romania, the Romanian Government has determined that a Master Plan for Tourism Development is urgently needed to lay the foundations for implementing a sustainable approach to tourism development in Romania. This Master Plan covers a 20-year period until 2026 and included a six-year action program (2007-2013) correlated with financial support through the structural instruments. The National Strategy for the Development of Ecotourism in Romania aims to present the current situation of the protected natural areas and the stage of development of ecotourism activities within and around them and to come up with a set of strategic proposals that will guide the efforts for valorization through ecotourism of these destinations, in 
accordance with the requirements imposed by the national legislation, as well as by the international conventions to which Romania adhered[3].

\section{THE CONTRIBUTION OF LOCAL ACTION GROUPS (LAGS) TO THE PROMOTION OF ROMANIAN TRADITIONS}

Local Action Groups (LAGs) are partnerships between local authorities and private and civil sectors. Their role is to develop and implement local development strategies that implement the objectives of the European Council Regulation (EC) 1698/2005 in the local area chosen by them. LAGs have the task of identifying and implementing a local development strategy, making decisions about the allocation of financial resources and administering them, in order to ensure the sustainable development of the territory they represent. [8].

There are countless Local Action Groups (LAGs) in Romania that strongly promote national traditions, including the Sucevita-Putna Local Action Groups (LAGs) and the Local Action Groups (LAGs) in the Land of Bucovina, which have an important contribution in increasing the attractiveness of the places on which they operate as tourist destinations. Every year, the two LAGs have a well-defined role in organizing the festival entitled "Traditions and Legends of Bucovina". Different localities have the opportunity to be present through the presentation stands, and the participants have the opportunity to watch folk groups from the participating localities and to present them various moments in the history of Moldova, such as the historical scene "Stefan, Your Majesty!" One particular feature of this festival is the construction of a wooden church and a "living museum of the Bucovina village", which includes traditional households in the localities in this area, made available to tourists so that they can experience authentic living, cuisine and traditional activities in the houses of Bucovina [8].

The two LAGs, together with the Suceava County Council, are able to include during the two days during the event exhibitions dedicated to agricultural producers in the Rădăuţi area, stands of folk craftsmen, tasting presentations of traditional gastronomic products in the county, legends evoking legends historical buildings of Bucovina and shows with folk songs and dances. Also, the particularity of the festival and the component of the promotion of tradition is also due to the organization of a woodcutting contest, which is attended by the gentlemen (name given to the forest workers who handle the logs with the goat) and a traction horses, as well as a ball of householders [8].

Through the "Traditions and Legends of Bucovina" festival, the organizers want to promote both specific authentic of Bucovina customs and the relevance of the implementation of the LEADER Axis (Liaison Entre Actions de Développement de l'Économie Rurale), the benefits of accessing the European Agricultural Fund for Rural Development and the active presence of the two LAGs in the community in the development, accessibility and preservation of culture and identity in Bucovina[8].

Transylvania also ranks first in the top tourist destinations in Romania. Transylvania is a historical and geographical region located within the Carpathian arch, one of the historical regions of Romania. Over time it was part of the
Roman Empire, the Kingdom of Hungary, and the Austrian Empire respectively. In the West and beyond, Transylvania is often associated with vampires (mainly due to Bram Stoker's novel Dracula) and the horror genre, although this region is also known for the scenic landscapes of the Carpathian Mountains and its rich history [3].

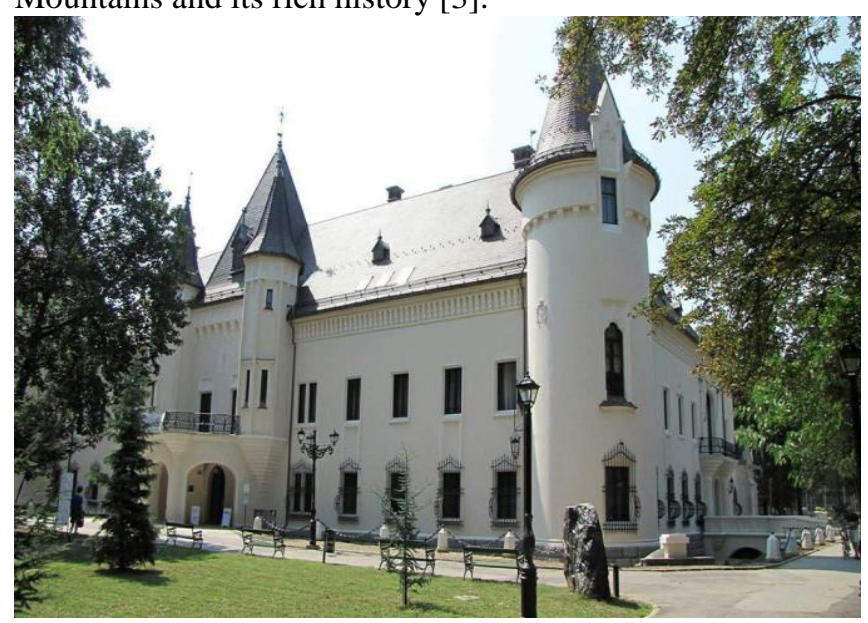

The Károlyi Castle in Carei (see image below), along with the Károlyi Fortress in Ardud, were renovated following a program of European funds. This is the access to Priority Axis 5, within the Regional Operational Program 2007-2013, Sustainable Development and Promotion of Tourism. Following the renovation and complete rehabilitation of the castle, the buildings have regained the glory of the past, becoming both multifunctional. To attract more visitors, the building provides various multifunctional or conference spaces. Events that are around 120-130 in number, per year, are organized both inside the castle and here we can talk about temporary exhibitions that are held every two weeks. In connection with outdoor events, we have several outdoor festivals taking place near the castle, more precisely in the Dendrological Park, which was also refurbished on the basis of European funds. [7]

The European Commission has launched a new call for projects under the COSME program in the field of tourism. The main purpose of this application is to strengthen the competitiveness and sustainability of the European tourism sector by encouraging the expansion of the tourist season, diversifying the EU tourism product and increasing its accessibility. In general, the Romanian tourist potential is diversified and balanced as a distribution, but at the regional level there is a greater concentration in the Southern Carpathians, with a significant number of mountain resorts, balneary and balneo-climatic resorts of national interest, but also locally Black Sea coast, respectively, in regions rich in cultural and folklore traditions such as: Transylvania (including Maramures and Banat), Bucovina and Moldova and Dobrogea [11]

Romania and Transylvania enjoy a rich offer for cultural tourism, but the specific infrastructure and support is not an asset. In general, cultural tourism shows the least economic efficiency, but this type of tourism can successfully associate with other more profitable forms of tourism (for example, with the business one), in particular, enjoys very rich and varied natural resources, which are, among other things, an excellent potential for the development of mountain tourism[12]. 


\section{CONCLUSION}

The tourism in Romania is based on the diversity of reliefs, natural landscapes, specific habits and rich history and tradition, as well as an important contribution to the country's economy. Tourism is considered to be one of the economic sectors of Romania characterized by dynamism. It is well known that Romania has the chance to enjoy a variety of reliefs, a unique cultural and historical dowry, the existence of natural monuments with unique character, some of which are included in UNESCO patrimony[6].

In the current economic crisis, many specialists consider tourism as one of the sectors with the highest potential to provide growth and economic development at international level. Today, tourism is one of the most dynamic economic sectors, which has a permanent changes and an upward trend. [2]. Tourism is an economic and social phenomenon of modern civilization, strongly anchored in the life of society and, as such, in a relationship of interconditionality with it. Thus, the trends registered in the evolution of the world economy, both positive ones, expressed by the increase of production and, on this basis, general prosperity, intensification of the international exchanges and widening the cooperation between states, industrialization and tertiary processes, as well as negative ones such as crises or periods of economic recession, the spread of poverty and unemployment, inflation, environmental degradation, have quantitatively and structurally influenced tourism activity, stimulating travel and diversifying their spatial orientation.

Some of the reasons for the continued increase in the popularity of special events may result from some demographic and psychographic changes that have taken place in specific sectors of the community such as: increasing the average available income level, increase in weekend holidays; increasing interest in experimental trips; increasing interest in authenticity; increasing interest in culture [2].

Thus, for foreigners Transylvania is a destination chosen for: visiting relatives and friends, relaxing, cultural interests and practicing rural tourism. In the case of the Romanians, especially tourism is practiced with the purpose of visiting relatives and friends; furthermore, their preferences are: weekend tourism and minivantes, respectively longer stays; cultural tourism and mountain tourism (summer hiking and winter sports). In short, Romania is a destination that enjoys a harmonious and diverse landscape, dubbed by traditions and a rich culture, being perhaps one of the most beautiful and resourceful places in the European space. Transylvania, as it turned out, is one of the favorite cultural destinations of foreigners arriving in Romania, being renowned for its multiethnic heritage, which makes it a familiar, easy to understand and understandable destination for European tourists, being a real sample of European cultural heritage [11].

The development and implementation of projects with European funding aimed at improving the key issues facing Romanian tourism, thus contributing to the process of sustainable development of tourist interest areas, should be a strong point. For the period 2014-2023, Romania has a total financial allocation of $€ 42.3$ billion to European funds $(€ 23$ billion are allocated to operational programs funded from structural and investment funds, $€ 8.1$ billion is allocated to the National Rural Development Program and $€ 11.2$ billion allocated to direct payments in agriculture). The different funds and programs reflect the diversity of tourism needs and the range of thematic programs of the EU that can support this accordingly. The tourism sector benefits from support from various programs, but gathering and understanding information about many programs remains a challenge for many of the private and public entities. The 2018-2020 period is a challenge for Romania both in terms of opportunities and risks[13].

\section{REFERENCES}

[1] Boniface P., Managing quality cultural tourism, Routledge, London, 1995.

[2] Croitoru M., Economie teoretică şi aplicată, Volumul XVIII (2011), No. 9 (562), p. 110.

[3] Dolea A.; Tarus A., Branding România. Cum (ne) promovam imaginea de tara, Curtea Veche, Bucuresti, 2009.

[4] Mazilu M. E., Opportunities and Threats for Romania as a Tourist Destination after the World Economic Crisis, 5th WSEAS International Conference on Economy and ManagementTransformation (EMT'10), Universitatea de Vest, Timişoara, 2010, p. 66-72.

[5] Qu H.; Kim L. H.; Im H. H., „A Model of Destination Branding: Integrating the Concepts of the Branding and Destination Image", in Tourism Management, Vol. 32, 2011, pp. 465-476.

[6] Paicu C.E., Implicațiile economice și comunicaționale ale turismului în România, Economie teoretică şi aplicată, Volumul XX, No. 7(584), 2013, pp. 105-115.

[7] Popescu R.I., Promovarea destinaţiilor turistice urbane prin implementarea managementului total al calităţii, Transylvanian Journal of Administrative Sciences 1 (21) / 2008, pp. 105-124.

[8] *** World Tourism Organisation, International Standardisation, European Standardisation Committee.

[9] ***Programul Național de Dezvoltare Rurală pentru perioada2014-2020, diponibil la: http://www.madr.ro/docs/dezvoltarerurala/programare-2014-2020/PN DR_2014_-_2020_01.07.2014.pdf

[10] https://ec.europa.eu/regional_policy/ro/policy/themes/tourism/ accessed on 07.07.2019.

[11] http://madr.ro/docs/dezvoltare-rurala/rndr/buletine-tematice/PT12.pdf , accessed on 07.07.2019.

[12] https://www.startupcafe.ro/bani-europeni/pelesul-transilvaniei-bani-e uropeni-circuit-turistic-vizitatori-evenimente.htm , accessed on 11.07.2019.

[13] https://www.europetour.tips/wp-content/uploads/2018/08/M7 Finant are RO-1.pdf, accessed on 10.07.2019. 